\title{
Isolation of Quercetin-3-o-beta-d-glucopyranoside from the Leaves of Azadirachta Indica and Antimicrobial and Cytotoxic screening of the Crude Extracts
}

\author{
Monirul Islam ${ }^{1}$, Md.Al-Amin ${ }^{1}$, M. Mahboob Ali Siddiqi ${ }^{2}$, Shakila Akter ${ }^{3}$, Mohammad Majedul Haque ${ }^{3}$, \\ Nasim Sultana $^{3}$ and A. M. Sarwaruddin Chowdhury ${ }^{*}$ \\ ${ }^{1}$ Department of Applied Chemistry and Chemical Engineering,Dhaka University, Dhaka-1000, Bangladesh \\ ${ }^{2}$ Institute of Natural Sciences, United International University, Dhaka-1209, Bangladesh \\ ${ }^{3}$ Analytical Research Division, Bangladesh Council of Scientific and Industrial Research, Dhaka-1205,Bangladesh
}

Received on 14. 01. 2010. Accepted for Publication on 10.09.2011

\begin{abstract}
Quercetin-3-O-beta-D-glucopyranoside was isolated from the ethylacetate soluble fraction of the ethanol extract of the fresh leaves of Azadirachta indica (Family: Meliaceae). The crude extract of hexane, ethylacetate and butanol soluble fractions of this ethanol extract were subjected to antimicrobial screening and brine shrimp lethality bioassay. The ethylacetate crude extract exhibited moderate antimicrobial activity against most of the test organisms and also showed significant cytotoxicity having $\mathbf{L} \mathbf{C}_{50} \mathbf{0 . 6 1} \mu \mathrm{g} / \mathrm{ml}$.
\end{abstract}

Key words: Azadirachta indica, Meliaceae, Quercetin-3-O-beta-D-glucopyranoside, Brine shrimp lethality bioassay, antimicrobial screening.

\section{Introduction}

Azadirachta indica (Bengali name-Neem; FamilyMeliaceae) is a small to large deep-rooted tropical tree with extremely bitter compound leaves, pinkish white small flowers in axillary panicles and one-seeded drupe type of fruits, grows wild and planted all over the country. ${ }^{[1,2]}$ Various parts of the plant are used in inflammation of gums, gingivities, sores, fevers (including malaria), spleen complaints, tumours, head, head scald, smallpox, diarrhoea and cholera. ${ }^{[1]}$ In addition, the leaves possess antiseptic properties and are used in boils, ulcers, aczema, ringworm and scabies. ${ }^{[3,4,5]}$ Aqueous and alcoholic extracts of the leaves and bark show good antibacterial activity. ${ }^{[\mathbf{6}]}$ Extracts of leaves, bark, gum and seeds are used as remedies for scorpion-sting, snake-bite, as antiviral, antineoplastic and antifungal agents. ${ }^{[7,8]}$ The gum is a demulcent tonic and is useful in catarrhal affections. Flowers are used in atonic dyspepsia and general debility. Seed kernel produces antidiabetic and abti-hyperlipaemic effect in alloxan diabetic rabbits. ${ }^{[4,9]}$ The oil is used in the treatment of ulcers, chronic skin diseases and rheumatism. Most of the constituents of the plant exhibit antibacterial and antiinflammatory effects. ${ }^{[10]}$

Previous phytochemical investigations with Azadirachta indica led to the isolation of triterpenoid bitter principles (nimbidin, nimbin, nimbinine, 6-desacetylnimbinine, nimbidol, nimbolide and bakayanin), saponins, flavonoids, tannins and alkaloids. In addition to these, the leaves contain azadirachtin, salanin, meliantriol, margosopicrin, paraisine, $\operatorname{azadinine}^{[5]}$, nimbinene, nimbolide, quercetin and its glycosides, beta-sitosterol, n-hexacosanol, nonacosane, ascorbic acid and amino acids. Barks contain nimbolins A, $\mathrm{B}$, organic acids, tannin, margosin and azadarin. Flowers contain essential oil, kaempferol, kaempferol glucoside, nimbosterin and $\mathrm{N}$-nonacosane. Fruits contain resins, tannins, triterpenoids, salanin and azadriachtin, melianone, oil and organic acids. Kernel contains triterpenoids, salanin,azadirachtin, oil and fatty acids. Seeds contain six tetranor-triterpenses and four new limonoids, 11-hydroxyazadirachtin-B, 1-tigloyl-3-cetyl-azadirachtin, 1,2-diacetyl7-tigloyl-12-hydroxylvilasinin and 23-desmethyl-limocin-B. Nim oil contains margosic acid. ${ }^{[1]}$ The isolation and structure elucidation of the antimalarial agent of the plant, gedunin, has been reported in 1989. ${ }^{[11]}$

\section{Materials and Methods}

\section{General experimental procedure}

The ${ }^{1} \mathrm{H}$ and ${ }^{13} \mathrm{CNMR}$ spectra were recorded using a Bruker AMX-400 (400 MHz) instrument. For NMR studies deuterated chloroform was used and the $\delta$ values for ${ }^{1} \mathrm{H}$ spectra were referenced to the residual nondeuterated solvent signals.

\section{Plant Material:}

The plant of Azadirachta indica was collected from Jessore district of Bangladesh which was identified by Bangladesh National Herbarium, Dhaka. A voucher specimen has been deposited in the Bangladesh National Herbarium, Dhaka (DACB Accession no. 32607), for the collection. The leaves were then washed with water to remove mud and dust particles. The leaves were first dried in room temperature and then in the oven. The dried leaves were grinded to powder by a cyclotec grinder (200 mesh) and the powder was stored for extraction in an air tight bottle.

\section{Extraction and Isolation}

The air dried and powdered plant material (600 gm) was soaked in ethanol for 7 days for the purpose of cold extraction. The extract was filtered through fresh cotton bed and finally Whatman No.1 filters paper. The filtrate was concentrated with a rotary evaporator at low temperature $\left(400-500^{\circ} \mathrm{C}\right)$ and reduced pressure. The weight of the crude 
extract was $54.4 \mathrm{gm}$. The concentrated ethanol extract was fractionated by the modified Kupchan partitioning method ${ }^{[12]}$ into hexane, ethylacetate and butanol soluble fractions. Evaporation of solvents afforded hexane (9.3), ethyl acetate (10.9) and butanol (6.7) extract. Ethyl acetate extract was taken for further fractionation. It was fractionated by Vacuum Liquid Chromatography (VLC) over silica gel using solvents of increasing polarity. The VLC fraction $(750 \mathrm{mg}$ ) obtained with $20 \% \mathrm{MeOH}$ in Ethyl acetate was subsequently subjected to Gel Filtration Chromatography (1.5 g) eluting with $\mathrm{CHCl}_{3}-\mathrm{MeOH}$ mixtures to give 30 fractions and sub fractions 6-16 were combined $(500 \mathrm{mg})$ and finally Column Chromatography using $20 \% \mathrm{MeOH}$ in Ethylacetate afforded the compound.

Bioassays. The antimicrobial activity of the crude extracts was determined by the disc diffusion method ${ }^{[13,14]}$. The extracts were dissolved separately in chloroform and applied to sterile filter paper discs at a concentration of $500 \mathrm{ug} / \mathrm{disc}$. Kanamycin disc (30ug/disc) was used as standard in each study. For cytotoxicity screening DMSO solutions of the compounds were applied against Artemia salina for 24 hours in a simplified in vivo simplified assay. ${ }^{[15,16]}$ In this experiment, the extracts were dissolved in DMSO and by serial dilution technique, solutions of varying concentrations such as 400, 200, 100, 50, 25, 12.50, 6.25, 3.125, 1.563, $0.781 \mu \mathrm{g} / \mathrm{ml}$ were obtained. Then each of these test solutions was added to test tubes containing 10 shrimps in simulated brine water $(5 \mathrm{ml})$.After $24 \mathrm{hrs}$, the median lethal concentration $\left(\mathrm{LC}_{50}\right)$ of the test samples was obtained by a plot of percentage of the shrimps killed against the logarithm of the sample concentration. Vincristine sulphate was used as positive control in this assay to compare the cytotoxicity of the extracts.

The Compound was isolated from the ethylacetate soluble fraction of an ethanol extract of the fresh leaves of Azadirachta indica (Family: Meliaceae) by repeated chromatographic separation and purification over silica gel. The structure of the isolated compound was determined by ${ }^{1} \mathrm{H}$ and ${ }^{13} \mathrm{C}$ NMR data analysis as well as by comparison with previously reported values. ${ }^{[17,18]} \mathrm{HRFAB}(+)$ MS showed m/z 465.2039 $[\mathrm{M}+1]^{+1}$, suggesting the molecular formula $\mathrm{C}_{21} \mathrm{H}_{20} \mathrm{O}_{12}$ and it also showed peak at $\mathrm{m} / \mathrm{z} 303.3505$ due to the loss of hexose. IR spectrum showed peaks at $3263.3 \mathrm{~cm}^{-1}$, $3344.3 \mathrm{~cm}^{-1}, 3448.8 \mathrm{~cm}^{-1}$ and $3581.6 \mathrm{~cm}^{-1}$ suggesting $\mathrm{OH}$ groups. Analysis of the UV spectrum utilizing shift reagents indicated the presence of hydroxyl groups at C-5, C-7, C-3', and $\mathrm{C}-4$.

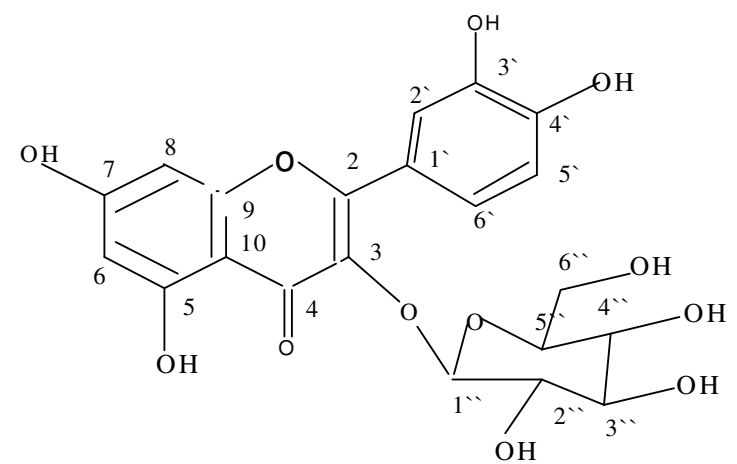

Fig. Structure of the Compound (Quercetin-3-0-beta-dgluco pyranoside)

The ${ }^{1}$ H NMR spectrum (Table-1) showed three aromatic protons signals at $7.71\left(\mathrm{~d}, \mathrm{~J}=2 \mathrm{~Hz}, \mathrm{H}-2^{\prime}\right), 6.87$ (d, J=8.4 Hz, $\mathrm{H}^{-5}$ ') and $7.58(\mathrm{dd}, \mathrm{J}=2,8.4 \mathrm{~Hz})$ in the form of an ABD spin-system suggesting a flavonol with 3 ,4`- disubstituted B-ring and showed a pair of meta coupling proton signals at $6.19(\mathrm{~d}, \mathrm{~J}=2 \mathrm{~Hz}, \mathrm{H}-6)$ and $6.38(\mathrm{~d}, \mathrm{~J}=2 \mathrm{~Hz}, \mathrm{H}-8)$ for the Aring. It also showed signals for glucose moiety, it showed signal at $\delta 5.23\left(\mathrm{~d}, \mathrm{~J}=7.6, \mathrm{H}-1^{\prime \prime}\right)$ indicated that compound posses $\beta$-linked glucose. The ${ }^{13} \mathrm{C}$ NMR (Table-2) spectra supported this hypothesis and showed 21 signals including carbonyl signal at $\delta 179.48(\mathrm{C}-4)$. It revealed chemical shifts at $\delta 135.64$ (C-3), 162.99 (C-5), 165.97 (C-7), 145.87 (C3'), 149.83 (C-4) that suggested the 3, 5, 7, 3', 4'oxygenated flavone nucleus. It showed significant glucose signals at $\delta 104.39$ (C-1“), 75.73 (C-2“), 78.11 (C-3“), 71.22 (C-4’'), 78.35 (C-5“), 62.58 (C-6“).

Table. $1 .{ }^{1} \mathrm{H}$ NMR (400 $\left.\mathrm{MHz}, \mathrm{CD}_{3} \mathrm{OD}\right)$ data for the compound

\begin{tabular}{|c|c|}
\hline Position of $\mathbf{H}$ & $\partial_{\mathbf{H}}(\boldsymbol{J}$ in $\mathbf{H z})$ \\
\hline 6 & $6.19(\mathrm{~d}, J=2)$ \\
\hline 8 & $6.38(\mathrm{~d}, J=2)$ \\
\hline 2 ` & $7.71(\mathrm{~d}, J=2)$ \\
\hline 5 & $6.87(\mathrm{~d}, J=8.4)$ \\
\hline 6 & $7.58(\mathrm{dd}, J=2,8.4)$ \\
\hline $4^{\prime \prime}$ & $5.23(\mathrm{~d}, J=7.6)$ \\
\hline $2^{\prime \prime}$ & $3.48(\mathrm{t}, J=9.2)$ \\
\hline $3^{\prime \prime}$ & $3.35(\mathrm{t}, J=8.8)$ \\
\hline $5^{\prime \prime}$ & $3.43(\mathrm{t}, J=9.6)$ \\
\hline 6 & $3.24(\mathrm{~m})$ \\
\hline
\end{tabular}


Table. 2. ${ }^{13} \mathrm{C}$ NMR data for the compound (400 MHZ, $\left.\mathrm{CD}_{3} \mathrm{OD}\right)$

\begin{tabular}{|c|c|}
\hline Position of $\mathrm{C}$ & $\partial_{\mathrm{c}} \mathrm{ppm}$ \\
\hline 2 & 158.44 \\
\hline 3 & 135.64 \\
\hline 4 & 179.48 \\
\hline 5 & 162.99 \\
\hline 6 & 99.89 \\
\hline 7 & 165.97 \\
\hline 8 & 94.73 \\
\hline 9 & 158.44 \\
\hline 10 & 105.68 \\
\hline 1 & 123.08 \\
\hline 2 & 117.59 \\
\hline 3 & 145.87 \\
\hline 4 & 149.83 \\
\hline 5 & 116.01 \\
\hline 6 & 123.20 \\
\hline $1 "$ & 104.39 \\
\hline $2^{\prime \prime}$ & 75.73 \\
\hline 3 & 78.11 \\
\hline $4^{\prime \prime}$ & 71.22 \\
\hline $5^{\prime \prime}$ & 78.35 \\
\hline $6^{\prime \prime}$ & 62.58 \\
\hline
\end{tabular}

On this basis, compound (1) was identified as Quercetin-3O-beta-D-glucopyranoside. The identity of this compound as Quercetin-3-O-beta-D-glucopyranoside was further substantiated by comparison of its spectral data with previously reported values. ${ }^{[17,18]}$

In the antimicrobial screening, the extractives of the Azadirachta indica exhibited poor and mild antimicrobial activity against most of the test organisms cited in table3.The zone of inhibition produced by the Ethylacetate extract ranged from $08-10 \mathrm{~mm}$, at a concentration of $500 \mu \mathrm{g} / \mathrm{disc}$.
Following the procedure of Meyer ${ }^{[15,16]}$, the lethality of crude extract of hexane, butanol and ethylacetate extracts were screened by brine shrimp lethality bioassay for probable cytotoxic activity. The $\mathrm{LC}_{50}$ obtained from the bestfit line slope were found to be $1.3,10.2$ and $0.61 \mu \mathrm{g} / \mathrm{ml}$ for hexane, butanol and ethylacetate extract respectively cited in table-4.In comparison with the positive control (vincristine sulphate), the cytotoxicity exhibited by hexane and ethylacetate extract was significant.

Table. 3. Antimicrobial activity of Azadirachta indica extracts $(500 \mu \mathrm{g} / \mathrm{disc})$ and Kanamycin $(30 \mu \mathrm{g} / \mathrm{disc})$

\begin{tabular}{|c|c|c|c|c|}
\hline Test bacteria and fungi & $\begin{array}{l}\text { Hexane } \\
\text { extract }\end{array}$ & Ethylacetate extract & $\begin{array}{c}\text { Butanol } \\
\text { extract }\end{array}$ & Kanamycin \\
\hline \multicolumn{5}{|l|}{ Gram Positive bacteria } \\
\hline Bacillus cereus & NA & 10 & NA & 36 \\
\hline Bacillus megaterium & NA & 10 & NA & 36 \\
\hline Bacillus subtilis & NA & 10 & NA & 36 \\
\hline Staphylococcus aureus & NA & 9 & NA & 35 \\
\hline \multicolumn{5}{|l|}{ Gram Negative bacteria } \\
\hline Escherichia coli & NA & 6 & NA & 38 \\
\hline Salmonella typhi & NA & 10 & NA & 35 \\
\hline Shigella boydii & NA & 8 & NA & 38 \\
\hline Vibrio mimicus & NA & 10 & NA & 34 \\
\hline \multicolumn{5}{|l|}{ Fungi } \\
\hline Candida albicans & NA & 10 & NA & 35 \\
\hline Aspergillus niger & NA & 10 & NA & 38 \\
\hline
\end{tabular}

"NA" Indicates 'No Activity'. 
Table. 4. $\mathrm{LC}_{50}$ data of Azadirachta indica extracts and vincristine sulfate.

\begin{tabular}{ll}
\hline Samples & $\mathrm{LC}_{50}(\mu \mathrm{g} / \mathrm{ml})$ \\
\hline vincristine sulphate $(\mathrm{Std})$. & 0.33 \\
Hexane extract & 1.3 \\
Butanol extract & 10.2 \\
Ethylacetate extract & 0.61 \\
\hline
\end{tabular}

\section{Acknowledgements}

The authors wish to thank the Bangladesh Council of Scientific and Industrial Research under Ministry of Science and Information \& Communication Technology, Government of the Peoples' Republic of Bangladesh.

1. Ghani,A., 2003. Medicinal Plants of Bangladesh, second edition, Asiatic Society of Bangladesh, Dhaka-1000: 69-70.

2. Dr. Md. Abdul Hassan and Khairul Alam.Plant Taxonomy, p.49.

3. Basak and Chakraborty, D. P., 1986, Journal of Indian Chemical Society, 45, 466-467.

4. Pillai, N.B., 1981, Planta Medica, 43(1), 59.

5. Said,H.M.(ed.), 1996,Medicinal Herbal, $1^{\text {st }}$ edn., Hamdard Foundation Pakistan.

6. Ahmed,S.P.,Ahmed,M.,Ahmed,S.I.,Najam,A. \& Khurshid, S. J. 1995. Pakistan Journal of Scientific and Industrial Research,38(11-12),448-450.
7. IJEB (Indian Journal of Experimental Biology).1969 \& 1971.

8. IJMR (Indian Journal of Medical Research).1969.

9. Bopanna, K.N.,Kannan, J., Gadgie, S., Balaraman, R.\&Rathod, S. P., 1997, Indian Journal of Pharmacology, 29(1), 162-167

10. Gupta,S. S. \& Mitra,C. R., 1953,Journal of Science, Food \& Agriculture,4,44-48.

11. Siddiqui, S., Siddiqui, B. S., Faizi,S. \& Mahmood,T.,1992, Journal of Natural Products, 55(3),303-310.

12. Wagenen, B. C. V., Larsen, R. J. H., Cardellina, H. D., Randazzo, Z. C. I. and Swithenbank, C.,1993. J. Org. Chem., 58: 335 .

13. Bauer, A.W., Kirby, W.M.M., Sherris, J.C. and Turck, M.1966. Antibiotic Susceptibility Testing by a Standardized Single Disc Method. Am. J. Clin. Pathol. 45, 493-496.

14. Nahar,K., Khan, M. G. U., Rahman,M.S., Begum, B. and Rashid,M.A.,2008.Antimicrobial and cytotoxic activities of Bryophyllum daigremontianum. Dhaka Univ. J. Pharm. Sci. 7(1): 99-101.

15. Meyer, B. N., Ferringni, N. R., Puam, J. E., Lacobsen, L. B., Nichols, D. E. and McLaughlin, J. L., 1982. Brine shrimp: a convenient general bioassay for active constituents. Planta Med. 45: 31-32.

16. Nishat,S.,Nahar,N.,Mamun,M.,Mosihuzzaman,M., and Sultana,N.,.2006.Neolignans Isolated from Seeds of Myristica Fragrans Houtt. Dhaka Univ. J. Pharm. Sci. 54(2): 229-231.

17. Markham, K. R., Ternai, B., Stanly, R. Geiger, H. and Mabry, T. J. 1978. Tetrahedron 34, 1389.

18. Agarwall, P.K. (1989). ${ }^{13}$ C NMR of Flavonoids. Elsevier, Amsterdam. 